\title{
Phase I, dose-escalation, clinical trial of MVA-Brachyury-TRICOM vaccine demonstrating safety and brachyury-specific T cell responses
}

\author{
Christopher R Heery ${ }^{1}$, Renee Donahue ${ }^{1 *}$, Lauren Lepone ${ }^{1}$, Italia Grenga', Jacob Richards', Simon Metenou', \\ Romaine I Fernando ${ }^{1}$, Ulrike Dirmeier ${ }^{2}$, Harpreet Singh ${ }^{3}$, Ravi Madan', James L Gulley ${ }^{3}$, Jeffrey Schlom ${ }^{1}$ \\ From 30th Annual Meeting and Associated Programs of the Society for Immunotherapy of Cancer (SITC \\ 2015) \\ National Harbor, MD, USA. 4-8 November 2015
}

\section{Background}

Brachyury is a tumor-associated antigen and transcription factor that drives the epithelial-to-mesenchymal transition in human carcinomas. This Phase I study assessed whether patients with advanced cancer or chordoma, a rare tumor of the notochord that overexpresses brachyury, can elicit brachyury-specific T cell responses following vaccination with MVA-Brachyury-TRICOM.

\section{Methods}

Patients with advanced cancer $(n=25)$ or chordoma $(n=13)$ enrolled on a Phase I clinical trial of MVA-brachyury vaccine (NCT02179515). Dose escalation was performed following $3+3$ design in 3 dose levels $\left(\mathrm{DL} 1=2 \times 10^{8}, \mathrm{DL} 2=4 \times 10^{8}, \mathrm{DL} 3=8 \times 10^{8}\right.$ plaque forming units, with vaccine administered in 3 cycles every 4 weeks). After safety was established, expansion cohorts were enrolled at DL2 and DL3 to compare brachyuryspecific-T cell responses. Peripheral blood mononuclear cells from pre- and post-vaccination ( $\sim$ day $29,57,85$, and 176) were stimulated with brachyury or HLA (negative control) 15-mer peptide pools and analyzed for brachyury-specific- $\mathrm{T}$ cell responses by intracellular staining of CD4 and CD8 T-lymphocytes for the cytokines IFN- $\gamma$, TNF, and IL-2, and the degranulation marker CD107a.

\section{Results}

In total, 3 patients enrolled on DL1, 17 on DL2, and 18 on DL3. On DL2 and DL3, 1 and 2 patients, respectively,

'Laboratory of Tumor Immunology and Biology, Center for Cancer Research, National Cancer Institute, National Institutes of Health, Bethesda, MD, USA Full list of author information is available at the end of the article were not evaluable for safety or immune responses and replaced. MVA-brachyury was well tolerated with no dose limiting toxicities. The maximal tolerated dose was not reached. Two deaths occurred on study, both due to complications of rapid disease progression, unrelated to vaccine. Two other serious adverse events (AEs) occurred, a hip fracture after a fall and a colonic obstruction due to disease progression. No serious adverse event was related to vaccine. AEs occurring in $>2$ unique patients included diarrhea (7.9\%), fever (18\%), flu-like symptoms (34\%), and injection site reaction (74\%). One grade 3 adverse event, diarrhea, was related to vaccine, and resolved without intervention after 48 hours. All other adverse events related to vaccine were grade 1 or 2 with short duration. Immune responses were analyzed in 29 patients. Brachyury-specific $\mathrm{T}$ cell responses were observed at each dose level: $66 \%(2 / 3)$ of patients at DL1, $80 \%(12 / 15)$ at DL2, and $90 \%(10 / 11)$ at DL3. At DL2 and DL3, $~ 80 \%$ of the patients that developed brachyury-specific- $\mathrm{T}$ cells demonstrated responses in both $\mathrm{CD} 4$ and CD8 T-lymphocytes.

\section{Conclusions}

These findings show for the first time that advanced cancer patients can be safely immunized with an MVAbased vaccine targeting brachyury, and can develop brachyury-specific T cell immune responses. These results warrant further studies using this vaccine in additional cohorts of cancer patients. 
Published: 4 November 2015

doi:10.1186/2051-1426-3-S2-P132

Cite this article as: Heery et al:: Phase I, dose-escalation, clinical trial of MVA-Brachyury-TRICOM vaccine demonstrating safety and brachyuryspecific T cell responses. Journal for Immunotherapy of Cancer 2015 3(Suppl 2):P132.

Submit your next manuscript to BioMed Central and take full advantage of:

- Convenient online submission

- Thorough peer review

- No space constraints or color figure charges

- Immediate publication on acceptance

- Inclusion in PubMed, CAS, Scopus and Google Scholar

- Research which is freely available for redistribution

Submit your manuscript at www.biomedcentral.com/submit
C) Biomed Central 